\title{
Kierkegaard and The Lover
}

\author{
M. Jamie Ferreira \\ U niversity of Virginia
}

«A believer, after all, is a lover; as a matter of fact, when it comes to enthusiasm, the most rapturous lover of all lovers is but a stripling compared with a believer.» (KW XIX, 103) In this judgment made by Anti-Climacus, Kierkegaard expresses a view found repeatedly in his writings - namely, that the lover is a particularly apt model for revealing dimensions of religious faith. W hat then isit to bea «lover»? T he figure of the lover winds its ways throughout Kierkegaard's writings, clothed in the concrete experience of aesthetic, ethical, and/or religious categories. As we would expect, «love» and «lover» are not used univocally in the pseudonymous and non-pseud onymous works. $\mathrm{N}$ or are those terms used univocally even within the context of the pseudonyms themselves: the picture of the lover found there is sometimes the aesthetic vision of aesthetic love, sometimes the ethical vision of aesthetic love, sometimes the aesthetic perspective on ethical love, sometimesthe ethical perspective on ethical love, and sometimes the aesthetic or ethical perspective on religious love. What are we to learn, or better, how are we to be enabled, through these varied portraits of the lover? Although I cannot do justice to that variety in these few pages, I want to indicate several of the ways in which an analysis of the «over» who is most in love can illuminate religious faith ${ }^{1}$. I will begin with a look at how Kierkegaard's late «deliberations» on «genuine» love, love of neighbor, expose a rich interplay between the passion and unconditionality which qualify love.

Kierkegaard's most explicit and lengthy account of love, Works of Love (1847) initial ly sets up astark contrast between preferential love and non-preferential love. Preferential love [Forkjerlighed] is said to be the heart not only of erotic love [Elskov], but also of friendship. Both are consigned to the domain of expressions of self-love since both are ways of loving «another-me»: «erotic loveand friendship are preferential love» and «passionate preference is actually another form of self-love.» (KW XVI, 52-53) Both friendship and love reduce to «the I intoxicated in the other I»- even «in love and friendship one's 
neighbor is not loved but one's other self, or the first I once again, but more intensely.»(KW XVI, 56-57) N on-preferential love [Kjerlighed], love of neighbor, on the contrary, is the paradigm of genuine love of an other because it is the paradigm of love for a genuine other. Later in Works of Love, we will discover K ierkegaard's normative proposal that L OVE IS U N SELFISH , L OVE IS FREE, and LOVE IS FAITH FU L. But before considering what is at stake in the model of unselfish, free, and faithful lover (as well as how this illuminates faith), it is important to note that Kierkegaard puts in question the starkness of his dichotomy between preferential and non-preferential love by his account of the relation between various expressions of love.

K ierkegaard takes pains throughout Works of L ove to remedy a variety of «misunderstandings» of the status of genuine love by indicating that they are not mutually exclusive; there is no existential "either/or" here. It is a «misunderstanding» to think that «n Christianity the beloved and the friend are loved faithfully and tenderly in quite a different way than in paganism.» (KW $X V I, 53)$ The goal is to «preserve love for the neighbor» in erotic love and friendship (KW XVI, 62). Kjerlighed is not a «higher love» in addition to erotic love and friendship (KW XVI, 45, 58); it is not a «more explicit definition» of pagan love (KW XVI, 142); it is not a different «ype» of love since there is «only onekind of love, the spirit's love» (KW XVI, 66, 143). It should «permeate» every expression of love (KW XVI, 112); it can and should «lie at the base of and be present in every other expression of love» (KW XVI, 146). G enuine loveallows «drives», «inclination», «feeling», «natural relations» and «prescriptive rights [...] to remain in force»; it is not indifferent to «family relations» or «friendship» or «fatherland». (KW XVI, 144). The sanctification it seeks is to «make everything new while everything is still old.» (KW XVI, 145) T he result - C hristianity «has not changed anything» («everything is still old») in the content of love and friendship, while it «has changed everything, has changed love as a whole.» (KW XVI, 147) I take these affirmations of unchanged content to suggest that the genuinely loving response addresses specific concrete human needs: the concreteness and distinctiveness of love do not necessarily compromise neighbor love, and, conversely, neighbor love does not necessarily jeopardize the concreteness and distinctiveness of love.

W hat do we learn from this suggestion that one does not leave erotic love or friendship behind in order to love someone as a neighbor, that love can be preserved and transfigured in a transforming experience? Welearn - againwhat we have already heard from Climacus- namely, that love is after all, whatever else it is, a passion. That is, it is a response of embodied, concrete persons to embodied, concrete persons ${ }^{2}$. If, then, faith can be fruitfully analo-

2. God's incorporeality would imply an imperfection in the analogy, but our embodiedness is central. Although K ierkegaard suggests that «passion» requires that we exclude «thethird», the context makes clear that heis rejecting the «preference» rather than the «passion»; moreover, he simply defines «sensuous, flesh» as «selfishness», so we cannot assume that he would see embodied concreteness as negative (KW XVI, 50, 52). 
gized with the passion of love, as Anti-C limacus suggests, we are reminded that the «happy passion» which C limacus terms «faith» (KW VII, 54, 59) is concretely embodied, as contrasted with the fantastic abstraction of an idealized pure intellect.

$\mathrm{H}$ ow else does the understanding of love as passion illuminate religious faith? First, K ierkegaard's various authors express an Aristotelian perspective on passion - for Aristotle, passions like love and anger illustrate a category which transcends the distinction between passive and active- we are responsible for our passions, they are our acts, even though they may not be done deliberately or «on purpose». W hen C limacus suggests that existence is «a time of falling in love», a «time for being in love», he hints at the passivity of love - yet he also describes existence as a «task», the task of existing in contradiction, the task of subjectivity. (KW XII.1, 396-397; 167, 314, 349-350) Love is a falling and a task - it is neither simply passive nor simply active. Passion is both passive and active, or better, it transcends the simplistic dichotomy between them.

A second characteristic of passion is that it is not something one has «to a certain degree». C limacus insists: «M uch that is strange has been said about enthusiasm, much that is deplorable, much that is outrageous, but the most obtuse thing said about it is that it is to a certain degree». Similarly, with erotic love: "the most obtuse thing said about it is that it is to a certain degree». (KW XII.1, 229) Passions like enthusiasm and love exhibit a threshold dimension: one is not somewhat in love or a little enthusiastic; rather, until a response has a particular quality, it is not yet love or enthusiasm at all. Faith, as a «happy passion», is similarly an integral, all-or-nothing, experience ${ }^{3}$.

W hat are the implications of passion's rejection of «a certain degree»? O ne implication is suggested through the connection Anti-C limacusmakes between a lover and a lack of reasons or defense. $\mathrm{H}$ e writes: «the most rapturous lover of all lovers is but a stripling compared with a believer. I magine a lover. Is it not true that he would be capable of speaking about his beloved all day long and all night, too, day in and day out? But do you believe it could ever occur to him, do you believe, it would be possible for him, do you not think he would find it loathsome to speak in such a manner that he would try to demonstrate by means of three reasons that there is something to being in love [...] do you believe that a lover would ever think of conducting a defense of his being in love, that is admit that to him it was not the absolute, unconditionally the absolute, but that he thought of it as being in a class with arguments against it and on that basis developed a defense.» «s it not obvious that the person who is really in love would never dream of wanting to prove it by three reasons or to defend it.» (KW XIX, 103, 104) In other words, as the medieval mystics like Eckhart, Silesius, and M arguerite Porete, were fond of saying, love is «without why.» 
The themes of "without degrees" and "without why" are converse sides of the idea of unconditionality, and Kierkegaard's description in Works of Love of genuine love as unselfish, free, and faithful illustratesthis unconditionality. «Learn», he says, «to love the living unselfishly, freely, faithfully.» (KW XVI, 358) That love is unselfish is one expression of how it is "without why". H is account of love as unselfish is elaborated in terms of the rejection of «repayment love» (G jenkjerlighed) ${ }^{4}$. That is, love is not conditional on anything given to us by the other. Love is without the "why" of a motive of either reward or a particular kind of response. The extreme of this- that love is not conditional on any response by the other- is found in the limit case of love of the dead. But this is a test case, for Kierkegaard, a heuristic device meant to clarify the purity of our motives ${ }^{5}$.

The freedom of love is another aspect of its being "without why". H ere Kierkegaard's point is that love is not conditional on any coercion, however, subtle, by the other. What is «extorted» from us cannot be love. (KW XVI, 351) Love is without the "why" of manipulation or pressure by the other. Finally, the fidelity which characterizes love can be phrased in terms of being "without why". What is at stake here is that love is not conditional on the other's faithfulness, support, or encouragement. O ne's love is not correlated on a one-to-one basis with the other's response; it does not vary with variations in the beloved. Love is without the "why" of being tied automatically to a change in the other. Again, the extreme case of irrel evance of response is found only in the limit case, the heuristic test, provided by love of the dead.

In sum, an analogy of faith with the passion of love suggests that faith is concretely embodied (rather than mere intellectual assent), not susceptible of «degrees», and «without why (without justification)». Elaborating the analogy through the dimensions of 'without why' in Works of Love, we can see that faith as love of God (or the following of C hrist) is absolutely unconditional. Indeed, one could argue that still another message is implicit in Kierkegaard's discussion of the test case of love of the dead: the message is that the test case for earthly love (love of the dead) parallels or prepares the soul for the test case of faith - namely, for the asymmetry of a «dark night». Kierkegaard's God is, after all, «a H idden God».

\section{Bibliography}

Conduding U nscientific Postscript to Philosophical Fragments, Kierkegaard's Writings XII.1 (1992). Trans. H oward V. and Edna H . H ong. Princeton: Princeton U niversity Press.

4. Unfortunately this is translated in the English version as «reciprocity», which can mislead as to what mutuality is allowed.

5. The «criterion» as found in remembering the dead emphasizes asymmetry, but the asymmetry of the test case is not a model for love because, as he insists, «without a you and an I, there is no love (even though with mine and yours, there is no love).» (KW XVI, 266) 
Philosophical Fragments, Kierkegaard's Writings, VII (1985). Trans. Howard V. and Edna H. H ong. Princeton: Princeton University Press.

TheSickness U nto D eath, Ki erkegaard's W ritings, XIX (1980). Trans. H oward V. and $\mathrm{E}$ dna $\mathrm{H}$. H ong. Princeton: Princeton University Press.

Works of Love, Kierkegaard's Writings, XVI (1995). Trans. H oward V. and Edna H. $\mathrm{H}$ ong. Princeton: Princeton U niversity Press. 